\title{
Reflexně seismický výzkum pozdně kenozoické zlomové tektoniky na vybraných lokalitách hornomoravského úvalu
}

\author{
Reflection-seismics survey of Late Cenozoic fault tectonics at selected sites of the \\ Upper Morava Basin
}

\section{Ondřej Bábek ${ }^{1} \square$, Zuzana Lendáková', Tamás Tóth² ${ }^{2}$, Daniel Šimíček' ${ }^{1}$, Ondřej Koukal'}

${ }^{1}$ Katedra geologie PřF Univerzity Palackého, 17. listopadu 12, 77146 Olomouc

${ }^{2}$ Geomega Kft., Zsil. Str. 1., 1093 Budapest, Hungary

Key words:

Shallow reflection seismics; horst-and-graben tectonics; continental siliciclastic deposits; Cenozoic; Bohemian Massif

$\rightrightarrows$ ondrej.babek@upol.cz

Editor:

David Buriánek

\begin{abstract}
We measured shallow reflection seismic profiles across the assumed faults in the Late Cenozoic (Pliocene-Holocene) Upper Morava Basin (UMB). The faults in the UMB are indicated by horst-and-graben morphology, differential thickness of Pliocene and Quaternary siliciclastic sediments, considerable gravity gradients a present-day seismicity. Four seismic lines, 380 to $860 \mathrm{~m}$ long (fixed geophone spread) were designed to cross the assumed faults at three sites, Mezice, Drahlov and Výšovice. The data were acquired by 24-channel ABEM Terraloc Mk-8 seismic system with PEG-40 accelerated weight drop source and processed by Sandmaier ReflexW and Halliburton Landmark ProMax seismic processing software. The processing included application of filters (DC shift, scaled windowgain, bandpass frequency and muting), stacking using normal moveout constant velocity stack, additional application of subtrack-mean (dewow) filter, topographic correction and low velocity layer static correction. Distinct reflectors were detected up to $400 \mathrm{~ms} T W T$, which corresponds to maximum depth of 280 and $350 \mathrm{~m}$ at 1400 and $1750 \mathrm{~km} \cdot \mathrm{s}^{-1}$ velocities, respectively. The observed reflection patterns were classified into three seismic facies, which were interpreted as crystalline rocks (Brunovistulicum) and/or well consolidated Paleozoic sedimentary rocks (SF1), unconsolidated Quaternary siliciclastic sediments (SF2) and semi-consolidated Neogene clays (SF3) based on the cores drilled in their close vicinity. Distinct faults were observed at the Drahlov and Výšovice 2 profile, which coincided with the observed topographic steps between the horsts and grabens. Presence of the fault at the Drahlov profile separating the Hnèvotín Horst from the Lutin Graben was demonstrated by independent electrical resistivity tomography profile. On the other hand, another topographic step at the Mezice profile, between the Hnèvotín Horst and Olomouc Graben, does not correspond to any seismic indication of a fault. The reflection seismics proved to be useful and relatively low-cost method to visualize the shallow subsurface geology in the Upper Morava Basin.
\end{abstract}

Úvod

Hornomoravský úval je hrástově-příkopovou strukturou, která se vytvořila na rozhraní Českého masivu a vnějších Západních Karpat v pozdním miocénu a dnes reprezentuje v podstatě jedinou dlouhodobě aktivní sedimentační pánev na povrchu Českého masivu. Tektonický původ pánve je naznačen řadou indicií, ke kterým patří výrazná morfologie (protáhlá příkopová propadlina omezená strukturními svahy ve směru SZ-JV), strmé tíhové gradienty podél linií ve stejném směru a diferenciální subsidence vyplývající z vrtných dat uvnitř pánve a z výchozů paleozoických hornin na jejím okraji (Dudek 1980; Špaček et al. 2015). Pánev hornomoravského úvalu (obr. 1) se přirozeně štěpí do několika liniových depocenter (mohelnická brázda, olomoucký prŕḱkop nebo hornomoravský 


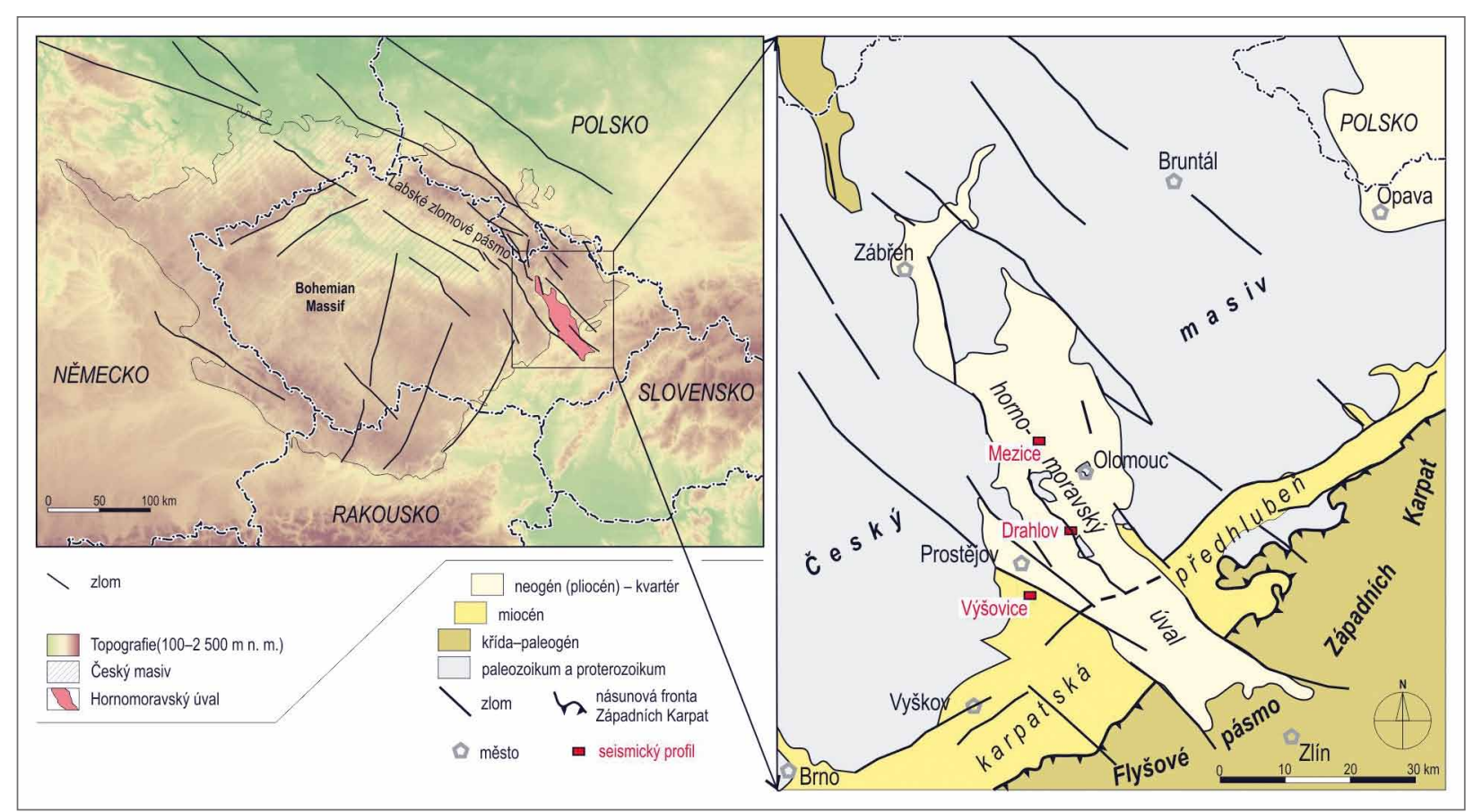

Obr. 1: Lokalizace hornomoravského úvalu v kontextu geologie střední Evropy.

Fig. 1: Localization of the Upper Moravian Basin in context of the Central European geology.

úval s. s., lutínský př́íkop, prostějovský příkop), ve kterých jsou dokumentovány dobře datované sedimenty pliocénu, svrchního pleistocénu a holocénu (Zeman et al. 1980; Čtyroký 1995; Zapletal 2005; Novák et al. 2017; Bábek et al. 2018) o úhrnné mocnosti až 300 m (Růžička 1989). Tato depocentra jsou oddělena hrástovými strukturami (hněvotínská a třebčínská elevace), ve kterých na povrch vychází starší horniny miocénu, paleozoika a dokonce krystalinické horniny brunovistulika (Dudek 1980; Zapletal 1985). Pozdně pleistocenní zlomová aktivita pánve byla dokumentována na základě OSL datování pretektonických spraší na kosířském zlomu (Špaček et al. 2017). Pánev zůstává tektonicky aktivní i v recentu, jak indikují ohniska monitorovaných zemětřesení, která se shlukují podél známých geologických rozhraní (např. temenický zlom na sv. okraji pánve, v širším okolí pak klepáčovský nebo bělský zlom).

Geomorfologie hornomoravského úvalu tak do značné míry odráží podpovrchovou tektonickou stavbu např. na zmíněných seismogenních zlomech. Modelace území je však zčásti ovlivněna erozní činností řeky Moravy v lokálních erozních bázích definovaných spádovou křivkou řeky. Ta se projevuje především boční erozí meandrů na okrajích meandrového pásu Moravy (obr. 2). Výrazné liniové topografické skoky, které jsou typické pro hornomoravský úval, tak mohou indikovat tektonické zlomy nebo jen okraje meandrových pásů. Cílem této práce je ověření původu topografických rozhraní uvnitř hornomoravského úvalu pomocí pozemní mělké reflexní seismiky, která se jeví jako perspektivní geofyzikální metoda pro cílové hloubky 50 až $200 \mathrm{~m}$.

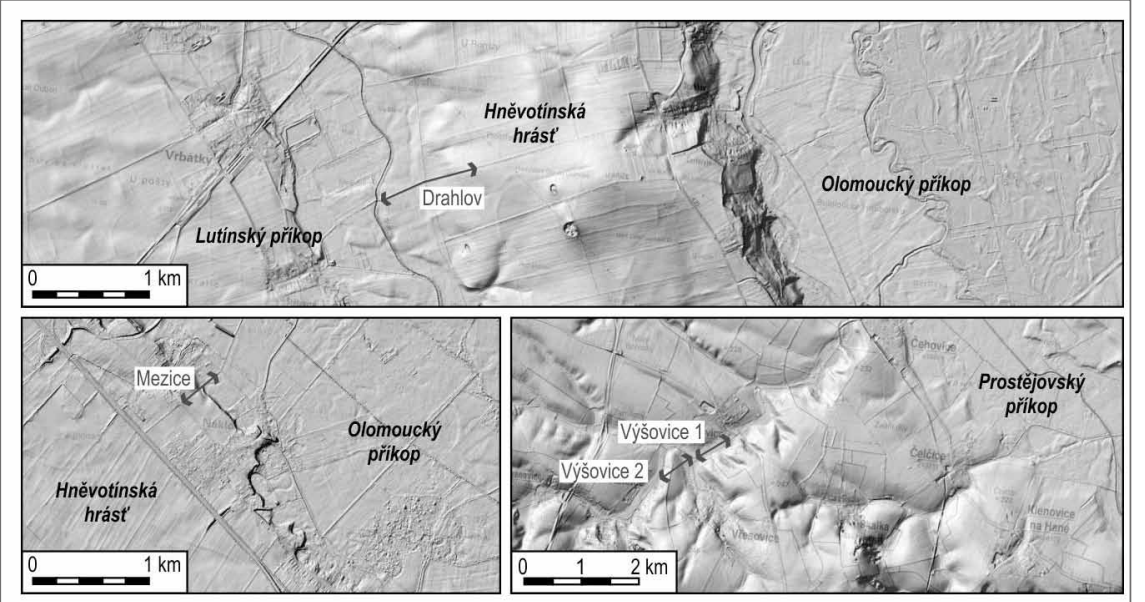

Obr. 2: Pozice měřených seismických profilů na rozhraní tektonických celků hornomoravského úvalu. Mapy převzaty z Geoportálu ČÚZK.

Fig. 2: Position of the reflection seismic profiles at the boundaries of tectonic units of the Upper Moravian Basin. The source of maps is Geoportal ČUZK.

\section{Metodika}

Reflexně seismické profilování bylo realizováno na 3 liniích (Mezice, Drahlov a Výšovice) s délkou roztažení geofonů (která zhruba odpovídá délce profilu) 0,37, 0,92 a $1,10 \mathrm{~km}$. K měření byl použit 24-kanálový seismograf Terraloc Mk-8 (ABEM Instruments, Švédsko) se zabudovaným softwarem SeisTW. Vzorkovací interval byl během měření nastaven na $100 \mu \mathrm{s}$, počet vzorků byl 16384 a čas přijmu 1638,4 ms. Reflexní seismické měření bylo prováděno v segmentech o délce 
Tab. 1: Lokalizace seismických profilů.

Tab. 1: Localization of seismic profiles.

\begin{tabular}{|c|c|c|c|c|c|c|c|}
\hline Profil & $\begin{array}{r}\text { Geofony: } 1 \\
\text { (W }\end{array}$ & $\begin{array}{l}\text { teční bod } \\
4)\end{array}$ & $\begin{array}{r}\text { Geofony: } \\
\text { (W }\end{array}$ & 4) & $\begin{array}{c}\text { Délka } \\
\text { (geofony) }\end{array}$ & Segmenty & CDP \\
\hline Drahlov & $\mathrm{N} 49^{\circ} 30,36997^{\circ}$ & E $17^{\circ} 13,83668^{\circ}$ & $\mathrm{N} 49^{\circ} 30,17100^{\circ}$ & E $17^{\circ} 13,19423^{\circ}$ & $860 \mathrm{~m}$ & 9 & 450 \\
\hline Mezice & $\mathrm{N} 49^{\circ} 39,46887^{\circ}$ & E $17^{\circ} 7,27798^{\prime}$ & $\mathrm{N} 49^{\circ} 39,61388^{\prime}$ & E $17^{\circ} 7,50200^{\circ}$ & $380 \mathrm{~m}$ & 4 & 200 \\
\hline Výšovice 1 & $\mathrm{~N} 49^{\circ} 24,79500^{\circ}$ & E $17^{\circ} 8,44302^{‘}$ & $\mathrm{~N} 49^{\circ} 24,62062^{\prime}$ & E $17^{\circ} 8,05052^{\prime}$ & $572 \mathrm{~m}$ & 6 & 300 \\
\hline Výšovice 2 & $\mathrm{~N} 49^{\circ} 24,61455^{\circ}$ & E $17^{\circ} 7,96425^{\circ}$ & $\mathrm{N} 49^{\circ} 24,40240^{\circ}$ & E $17^{\circ} 7,61342^{\prime}$ & $572 \mathrm{~m}$ & 6 & 300 \\
\hline
\end{tabular}

$92 \mathrm{~m}$. V každém segmentu bylo uspořádáno 24 jednosložkových vertikálních geofonů SM-4B s pravidelnou roztečí $4 \mathrm{~m}$, tj., 1. geofon na $0 \mathrm{~m}, 2$. geofon na $4 \mathrm{~m}, 24$. geofon na $92 \mathrm{~m}$ segmentu. Jako zdroj seismických vln bylo použito akcelerované závaží PEG-40 („Propelled Energy Generator“, RT Clark, OK, USA) tažené na závěsném vozíku za osobním automobilem. Závaží o hmotnosti $40 \mathrm{~kg}$ je při pádu na kovovou desku urychleno pomocí elastomerového pásu. Pro každý segment bylo provedeno 14 odpalů s pravidelnou roztečí $8 \mathrm{~m}$, které byly umístěny v relativní vzdálenosti 90 m (1. odpal) až 194 m (14. odpal) od bodu 0 každého segmentu. $Z$ tohoto geometrického uspořádání plyne, že výsledný seskupený profil (stack) $\mathrm{v}$ každém segmentu obsahuje celkem 50 společných reflexních bodů (common depth points, CDP) s roztečí $2 \mathrm{~m}$. V každém odpalovém místě bylo sečteno (stacking) 4 až 7 odpalů pro posílení poměru signál/šum. Za jeden den je možné v týmu 3 operátorů naměřit typicky 4 až 5 segmentů. Celkem bylo na 4 profilech (Mezice, Drahlov, Výšovice 1 a Výšovice 2 naměřeno 25 segmentů (tab. 1), což obnáší cca 5 dnů terénních prací. Lokalizace profilů jsou uvedeny v tabulce 1 .

Naměřená data na profilu Výšovice byla zpracována v programu ReflexW (Sandmeier Inc., Německo); data na profilech Drahlov a Mezice byla zprácována v programu SeisSpace ProMax $^{\circledast}$ (Halliburton Landmark). Hrubá data $\mathrm{z}$ profilů byla nejprve filtrována pomocí DC shift, scaled windowgain, bandpass frequency a muting/ surgical muting filtrů s cílem odstranit stejnosměrný proudový šum př́istroje, zesílit signál, normalizovat signál na vzdálenost od zdroje, odstranit nežádoucí frekvence a odstranit povrchové (groundroll), přímé a lomené vlny (direct / refracted wave). Výsledné profily byly seskupeny (stacking) s použitím funkce pro kinematickou korekci s konstantní rychlostí (NMO constant velocity stack). Tyto rychlosti byly opakovaným testováním empiricky vyhodnoceny jako nejvhodnější pro správné seskupení stop. Seskupené profily byly dodatečně upraveny pomocí subtrack-mean (dewow) filtru. Ve výsledných profilech byla provedena topografická korekce. Na profilu Drahlov a Mezice byla provedena statická korekce na př́povrchovou nízkorychlostní vrstvu (low velocity layer static correction).

\section{Výsledky a diskuze \\ Seismické facie}

Ve všech měřených profilech byly zastiženy zřetelné odrazy, které umožňují geologické intepretace. Signál reflexů je dobře patrný až do dvoucestné doby návratu (TWT) cca 400 ms (profil Výšovice). Rychlostní analýzou provedenou během kinematických korekcí byly identifikovány seismické rychlosti v rozmezí $1400 \mathrm{~m} / \mathrm{s}$ (Výšovice 1 a 2) až $1750 \mathrm{~m} / \mathrm{s}$ (Drahlov a Mezice), které pro TWT 400 ms indikují přibližný hloubkový dosah 280 až $350 \mathrm{~m}$ pod povrchem. Na základě prrítomnosti/nepřítomnosti odrazů, geometrie reflektorů (laterální kontinuita, úklon, zakřivení) a amplitudy odrazu (cf. McQuillin et al. 1979; Eberli et al. 2004) byly $\mathrm{v}$ měřených profilech identifikovány seismické facie SF1-SF3 (obr. 3).

SF1 zahrnuje chaoticky uspořádané, laterálně neprůběžné reflektory; případně reflektory zcela chybějící v doménách, které jsou pro seismické vlny transparentní. Tato facie byla zastižena na profilu Drahlov v metráži 0-380 m v úrovních dvoucestné doby návratu (TWT) 120 až > $280 \mathrm{~ms}$, na témže profilu v metráži cca 760-900 m v úrovních TWT 200 až $>280 \mathrm{~ms}$. Na profilu Mezice je tato facie zastižena po celé délce v úrovních TWT > $250 \mathrm{~ms}$. SF1 lze dále pozorovat na profilu Výšovice $2 \mathrm{v}$ metráži 250-600 m v úrovních TWT > $200 \mathrm{~ms}$.

Facie SF2 zahrnuje dobře omezené, laterálně kontinuální horizontální a subhorizontální reflektory s vysokou amplitudou a relativně krátkou vlnovou délkou. Tato facie byla zastižena na profilu Drahlov v metráži 500 až 900 m v úrovni TWT 120-220 ms, na profilu Mezice v celé délce profilu v úrovni TWT $\sim 80-250 \mathrm{~ms}$, a na profilu Výšovice 2 v metráži 250-600 m v úrovni TWT 100-200 ms.

Facie SF3 sestává z dobře omezených, laterálně kontinuálních subhorizontálních reflexů s vysokou amplitudou, ale přibližně dvojnásobnou vlnovou délkou než SF2. Reflexy mají místy mírné úklony, naznačují místy progradační geometrie a možnou existenci paleokoryt. SF3 byla zastižena pouze na profilu Výšovice 1 (v celé délce) a Výšovice 2 (metráž 0-250 m) v úrovních TWT $100-\sim 400 \mathrm{~ms}$.

\section{Geologická interpretace}

Na profilu Drahlov bylo zaznamenáno významné rozhraní v metráži cca 400-450 m, kde se laterálně mění seismické facie z SF1 ve vsv. části do SF2 v zjz. části profilu. Toto geofyzikální rozhraní odpovídá topografickému gradientu od cca $230 \mathrm{~m} \mathrm{n.} \mathrm{m.} \mathrm{(VSV)} \mathrm{do} 209 \mathrm{~m}$ n. m. (ZJZ). Tento morfologický skok představuje rozhraní mezi hněvotínskou hrástí a lutínským př́kopem. Nalezené geofyzikální rozhraní tak můžeme interpretovat jako poklesový zlom, na kterém je lutínský př́kop zakleslý. Facii SF2 zde interpretujeme jako pliocenní a kvartérní sedimenty lutínského př́íkopu, které byly ověřeny například vrtem 2220-B ( 1,4 km jz. od konce profilu) (Gilíková et al. 2015) a vrtem Hrdibořice HR1 (Novotný 2013; Novák et al. 2017). Naopak ve hněvotínské hrásti vystupují 


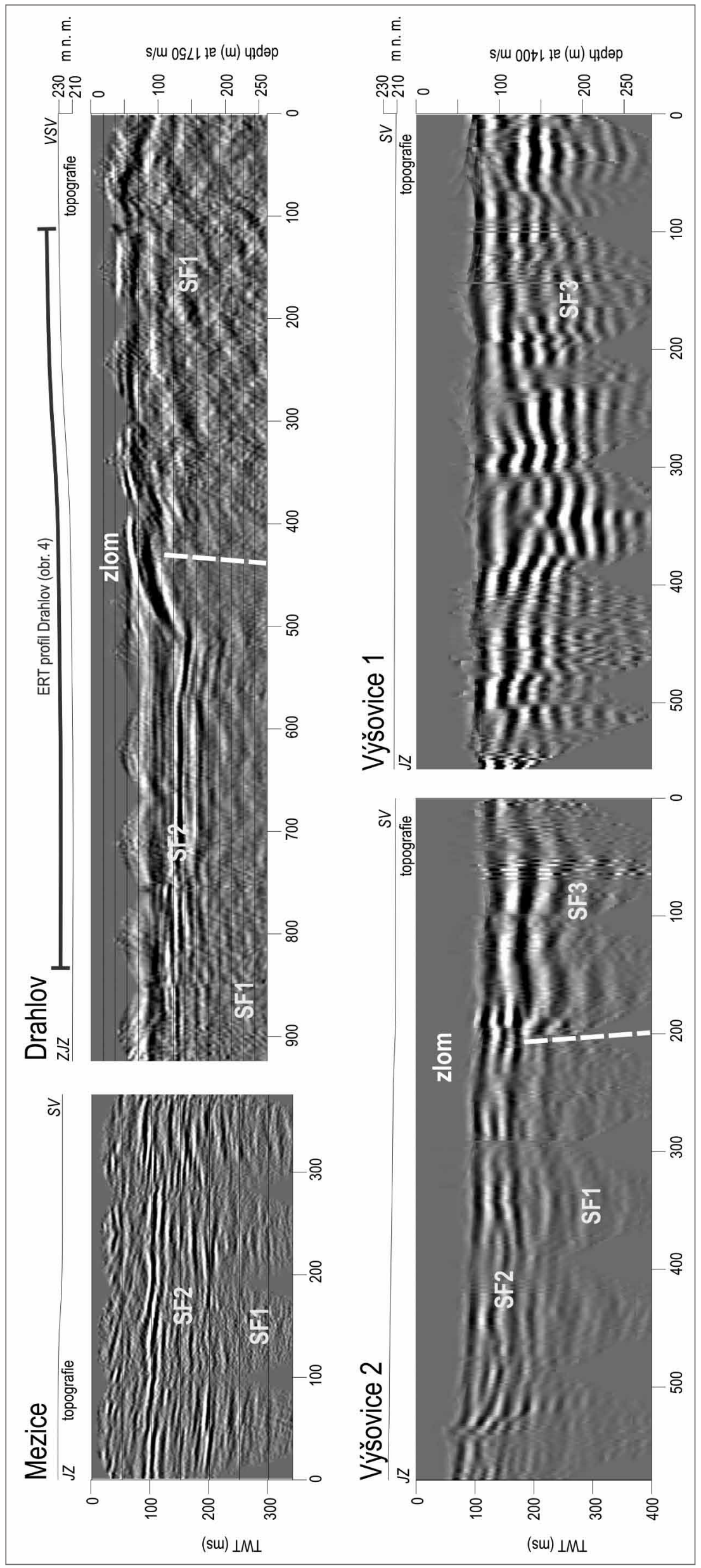

na povrch granity a granodiority brunovistulika, ověřené na výchozech (Drahlov, cca $1 \mathrm{~km}$ jv. od profilu) a ve vrtu 2220-D ( 2 km j. od počátku profilu) (Jankovský et al., 2015), a devonské dolomity (Bystročice, cca $5 \mathrm{~km} \mathrm{ssv.}$ od profilu).

Podél linie Drahlov byl změřen profil metodou elektrické odporové tomografie (ERT) (Špaček et al., nepublikovaná data), který ukazuje výrazné odporové rozhraní v metráži cca $400 \mathrm{~m}$ (obr. 4), tedy zhruba ve stejném místě, kde se projevuje zlomová tektonika na seismickém profilu. Ve vyzdviženém bloku hněvotínské hrásti byly zaznamenány měrné odpory v rozsahu $\sim 300$ až 2 000 S.m (krystalinické horniny, paleozoické sedimentární horniny?), zatímco v zakleslém bloku lutínského př́kopu se rezistivity pohybují v rozmezí $\sim 15$ až $\sim 200$ S.m (pliocenní-kvartérní nezpevněné klastické sedimenty). Oba bloky jsou odděleny výraznou vodivou zónou s měrnými odpory $\sim 5$ až $\sim 20$ S.m, kterou interpretujeme jako zlom.

Podobné tektonické rozhraní je patrné na profilu Výšovice 2 v metráži cca $250 \mathrm{~m}$, na kterém laterálně přecházejí facie SF2 + SF1 (JZ) do facie SF3 (SV), které pak pokračují k SV podél celého profilu Výšovice 1 . Cca $500 \mathrm{~m}$ s. od profilu Výšovice 1 je situován vrt č. II (GDO 656625), který provrtal 13,5 m kvartérních sedimentů a pod nimi neogenní jíly až do hloubky $149 \mathrm{~m}$. Další vrt HV-1 (GDO 434598) zastihující $75 \mathrm{~m}$ neogenních (pliocén) jílů leží cca $1 \mathrm{~km}$ sv. od profilu. Tyto sedimenty lze tedy srovnat s facií SF3. Naproti tomu j. až jv. od profilu je situován vrt HJP-115 (GDO 434452), ve kterém byly $\mathrm{v}$ hloubce $18,5 \mathrm{~m}$ pod 


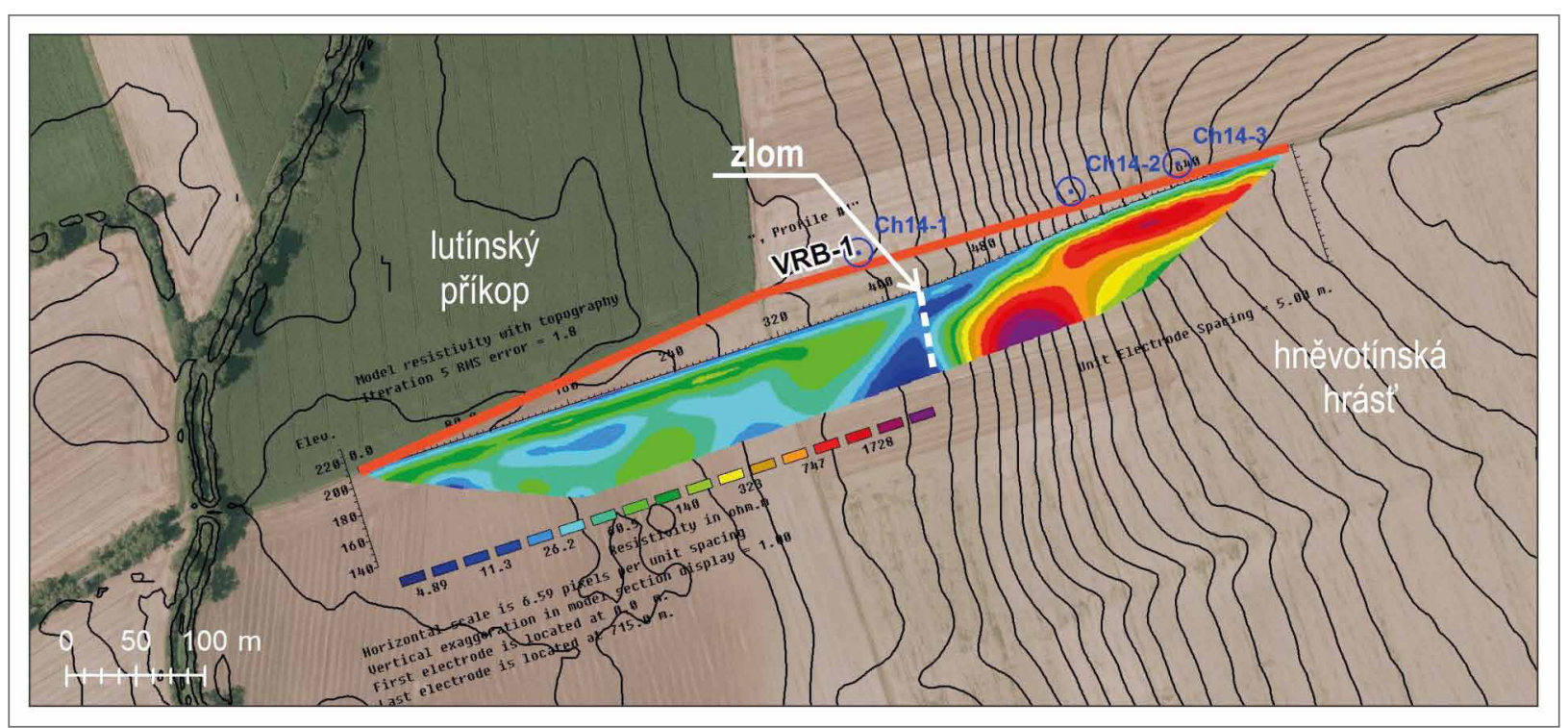

Obr. 4: Profil elektrické odporové tomografie (ERT) na linii Drahlov s geologickou interpretací (viz text).

Fig. 4: Electrical resistivity tomography (ERT) profile at the Drahlov line with geological interpretation (see text).

povrchem navrtány kulmské droby a konglomeráty u obce Vřesovice, kde se rovněž nachází výchoz kulmských hornin. Geofyzikální rozhraní na profilu lze interpretovat jako zlomové rozhraní oddělující zakleslé neogenní jíly od vyzdviženého bloku s kulmskými sedimenty, které interpretujeme jako facii SF1 (?) a kvartérním pokryvem, který interpretujeme jako SF2 (?). Hlavní topografický skok mezi uvedenými bloky probíhá ve směru SV-JZ víceméně paralelně s profilem. Tento svah však bohužel nebyl překř́ižen seismickým profilem.

Profil Mezice byl vytýčen přes velmi výrazné morfologické rozhraní hněvotínské hrásti a olomouckého př́íkopu s výškovým skokem $6 \mathrm{~m}$. Na výsledném seismickém profilu jsou však zastiženy víceméně průběžné reflektory facie SF2, které podle okolních vrtů nejlépe odpovídají kvartérním sedimentům (spraše a fluviální sedimenty). $\mathrm{V}$ jejich podloží byly vrty OL-3 $(\sim 0,7 \mathrm{~km} \mathbf{j}$. od počátku profilu) a HV-1027 ( 0,5 km v. od konce profilu) zastiženy pliocenní jíly v hloubkách cca 40 až $150 \mathrm{~m}$ pod povrchem (Paulík 1959; Kupec et al. 1972). Geofyzikální obraz na profilu Mezice nenaznačuje př́tomnost zlomového rozhraní. Morfologický skok lze interpretovat jako produkt boční eroze meandrů řeky Moravy, která protéká ve vzdálenosti cca $3,5 \mathrm{~km}$ od profilu, avšak v identické nadmořské výšce $225 \mathrm{~m}$, v jaké končí profil Mezice. V okolí lokality Mezice byly změřeny 2 ERT profily - Náklo a Rozvadovice (Bábek et al. 2018, obr. 5), které zasahují do hloubek cca $20 \mathrm{~m}$ pod povrchem. Na profilu Náklo je patrný odporový rozdíl mezi vyvýšenou oblastí hněvotínské hrásti s pokryvem spraší a depresí olomouckého př́kopu (fluviální sedimenty), který autoři s otazníkem interpretují jako možný zlom. Seismický profil uvedený $\mathrm{v}$ této práci však tuto interpretaci nepotvrzuje.

\section{Závěr}

Mělká reflexní seismika s akcelerovaným závažím PEG-40 je perspektivní a finančně nepř́liš náročnou metodou pro mapování mělkých zlomů a interpretovatelných seismických facií v cílových hloubkách $\sim 50$ až $350 \mathrm{~m}$. Tři zjištěné seismické facie lze porovnáním s místními vrty interpretovat jako krystalinikum brunovistulika př́padně zpěvněné sedimentární horniny kulmské facie karbonu moravskoslezské oblasti (SF1), nezpevněné kvartérní klastické sedimenty (SF2) a neogenní jíly (SF3).

$\mathrm{V}$ rámci této studie byly seismicky ověřeny dvě morfologicky výrazné zlomové struktury: zlomové rozhraní hněvotínské hrásti a lutínského př́íkopu u Drahlova a jeden ze zlomů na jz. okraji prostějovského př́kopu. Existence zlomových rozhraní dobře zapadá do interpretace lokální geologické blokové stavby indikované vrtnými daty a v př́padě lokality Drahlov i nezávislých geofyzikálních dat získaných metodu ERT. Naproti tomu, morfologický svah omezující hněvotínskou hrást' oproti olomouckému př́kopu u Mezic se v seismickém záznamu neprojevuje zlomovou tektonikou a topografický skok zde můžeme interpretovat jako erozní rozhraní způsobené boční erozí meandrující řeky Moravy.

\section{Poděkování}

Autoři děkuji Mateji Chovancovi, Dominiku Cholastovi, Jakubu Solgovi, Janu Kardinálovi (všichni PřF UP) a Martinu Bábkovi za pomoc prí terénních pracích, Petru Špačkovi (MU) za souhlas publikováním ERT profilu Drahlov, Zuzaně Skácelové (ČGS) za podnět pro měřní na lokalitě Výšovice a konzultaci dat, a České geologické službě za možnost publikovat komerční data. Autoři dále děkují recenzentưm Josefu Havírovi a Zuzanè Skácelové za pečlivé korektury rukopisu. Zuzana Lendáková, Daniel Šimíče a Ondřej Koukal provádèli terénní práce a zpracovali seismická data v programu ReflexW, Tamás Tóth zpracoval data v programu ProMaxं, Ondřej Bábek vytvořil návrh studie na lokalitě Drahlov a Mezice, podílel se na terénních pracích a sepsal draft rukopisu. Všichni autoři se podíleli na interpretaci seismických dat. 


\section{Literatura}

Bábek, O., Sedláček, J., Novák, A., Létal, A. (2018). Electrical resistivity imaging of anastomosing river subsurface stratigraphy and possible controls of fluvial style change in a graben-like basin, Czech Republic. - Geomorphology, 317, 139-156.

Čtyroký, P. (1995). Stratigrafie svrchního miocénu a pliocénu Hornomoravského úvalu. - Zprávy o geologických výzkumech v roce 1994, $28-32$.

Dudek 1980: The crystalline basement block of the Outer Carpathians in Moravia: Bruno-Vistulicum. - Rozpr. Čs. akad. věd, R. mat.-prír., 90,8, 1-85. Praha.

Eberli, G. P., Anselmetti, F. S., Betzler, C., Van Konijnenburg, J.-H., Bernoulli, D. (2004). Carbonate Platform to Basin Transitions on Seismic Data and in Outcrops: Great Bahama Bank and the Maiella Platform Margin, Italy. - In. Eberli, G. P., Masaferro, J. L, Sarg, J. F. (eds): Seismic Imaging of Carbonate Reservoirs and Systems. Americal Association of Petroleum Geologists Memoir 81, Tulsa, OK.

Gilíková, H., Hanák, J., Otava, J., Procházka, M., Skácelová, Z., Starý, J., Tomanová Petrová, P., Vít, J. (2015). Rebilance zásob podzemních vod. Závěrečná zpráva průzkumného geologického vrtu 2220_B Štětovice. Souhrnná dokumentace. - MS, Česká geologická služba. Praha.

Jankovský, F., Mlčoch, B., Otava, J., Skácelová, Z., Starý, J., Vrána, S. (2015). Rebilance zásob podzemních vod. Závěrečná zpráva průzkumného geologického vrtu 2220_D Dub nad Moravou. Souhrnná dokumentace. - MS, Česká geologická služba. Praha.

Kupec, J., Malý, J., Starobová, M. (1972). Střední Morava. Závěrečná zpráva o regionálním hydrogeologickém průzkumu fluviálních uloženin řeky Moravy a jejích príítoků. - MS, závěrečná zpráva. GEOtest, a.s. Brno.

McQuillin, R., Bacon, M., Barclay, W. (1979). An Introduction to Seismic Interpretation. Graham and Trotman Limited. 199 pp.

Novák, A., Bábek, O., Kapusta, J. (2017). Late Quaternary tectonic switching of siliciclastic provenance in the strike-slip-dominated foreland of the Western Carpathians; Upper Morava Basin, Bohemian Massif. - Sedimentary Geology, 355, 58-74.

Novotný, M. (2013). Geologický průzkum pro zjištění stáří sedimentů nivy řeky Moravy v Hornomoravském úvalu na lokalitách Dub nad Moravou, Hrdibořice, Hněvotín a Pňovice. - MS, závěrečná zpráva. GEOtest, a.s. Brno.

Paulík, J. (1959). Zpráva o přehledném geologickém výzkumu neogénu pro generální mapu ČSR, na listech Olomouc a Ostrava za r. 1958. - MS, závěrečná zpráva. Ústřední ústav geologický. Praha.

Růžička, M. (1989). Pliocén Hornomoravského úvalu a Mohelnické brázdy. - Sborník geologických věd, Antropozoikum, 19, 129-151.

Špaček, P., Bábek, O., Štěpančíková, P., Švancara, J., Pazdírková, J., Sedláček, J. (2015). The Nysa-Morava Zone: an active tectonic domain with Late Cenozoic sedimentary grabens in the Western Carpathians' foreland (NE Bohemian Massif). - International Journal of Earth Sciences, 104(4), 963-990.

Špaček, P., Valenta J., Tábořík J., Ambrož P., Urban V., Štěpančíková P. (2017). Fault slip versus slope deformations: Experience from paleoseismic trenches in the region with low slip-rate faults and strong Pleistocene periglacial mass wasting (Bohemian Massif). - Quaternary International, 451, 56-73.

Zapletal, J. (1985). Př́íspěvek ke geologii drobných výskytů kulmu v okolí Olomouce. - Acta Universitatis Palackianae Olomucensis, Facultas Rerum Naturalium, Geographica-Geologica XXIV, 83, 81-100.

Zapletal, J. (2005). Poznámky ke geologickému vývoji severozápadní části hornomoravského úvalu. - Geologické výzkumy na Moravě a ve Slezsku, 12(2005), 69-71.

Zeman, A., Havlíček, P., Minaříková, D., Růžička, M., Fejfar, O. (1980). Kvartérní sedimenty střední Moravy. - Sborník geologických věd, Antropozoikum, 13, 37-85. 